\title{
Participatory fisheries management for livelihood improvement of fishers in Phewa Lake, Pokhara, Nepal
}

\author{
Tek B Gurung ${ }^{1 *}$, Suresh K Wagle ${ }^{1}$, J ay D Bista ${ }^{1}$, Ram P Dhakal ${ }^{1}$, Purushottam LJ oshi², Rabindra Batajoo ${ }^{3}$, \\ Pushpa Adhikari ${ }^{4}$ and Ash K Rai ${ }^{5}$
}

1 Agriculture Research Station (Fisheries), Nepal Agricultural Research Council, Pokhara, NEPAL

2 Kali Gandaki Fish Hatchery, Beltari Syangja, NEPAL

3 Cold Water Fisheries Development Center, Kali Gandaki, Syangja, NEPAL

4 Agriculture Development Office, Kaski, NEPAL

5 Fisheries Research Division, Nepal Agricultural Research Council, Lalitpur, NEPAL

*To whom correspondence should be addressed.E-mail: fishres@fewanet.com.np

\begin{abstract}
This paper deals with the participatory fisheries management program, aimed at and successful in livelihood improvement of fisher community known as 'Pode' or 'J alari' living near Phewa Lake, Pokhara, Nepal. The community, traditionally depending on fishing activities for their livelihood, led a nomadic life along the rivers and lakes, carrying cast nets to feed their families. In the early 1960s, when the fish catch declined due to over fishing, the Pode's only source of livelihood was threatened. Meanwhile, the Fisheries Development Center, now Agriculture Research Station (Fisheries), was established in Pokhara in 1962 with the objective of assisting the poorest fishing communities through cage fish culture and open water fisheries. To begin with, each family was enabled to buy a single $50 \mathrm{~m}^{3}$ cage in order to start farming fish; the loans were underw ritten by the local Agriculture Development Bank. The total fish


recapture fisheries). The income from fish production is shared among local fisher families; it has brought substantial changes in the livelihood of the fisher community. A few years ago, it was difficult to find a literate member of the Pode community, but these days many children attend school and some even college. The community has realized the importance of lake resources and devised a code of conduct for sustainable fishery. The improvement on livelihood of fisher community is attributable to the combination of participatory fisheries management with their traditional skill on fish handling as well as their easy access. Apart from supporting in livelihood of poor communities, participatory fisheries management also contributes in maintaining ecological balance of aquatic ecosystems.
\end{abstract}

Key words: 'Pode', sustainable fishery, Phewa, cage culture, livelihood

Himalayan J ournal of Sciences 3(5): 47-52, 2005

Available online at: www.himjsci.com
Received: 12 Feb 2005

Accepted after revision: 20 May 2005
Copyright@ 2005 by Himalayan Association for the Advancement of Science (HimAAS)
Small scale fishers, especially those on inland waters, are among the poorest of the rural poor in developing countries facing apparently insurmountable obstacles in the existing economic and social power structures as they attempt to better themselves (Berkes et al. 2001). However, a participatory approach can overcome these obstacles (Jiggins and de Zeeuw 1992, Van de Fliert et al. 1999). Ideally, a participatory approach to fishery creates an integrated development strategy by fostering new relationships, ways of thinking, and structures and processes (Campbell and Salagrama 2000). The participatory approach paradigm in research and development completely differs from the conventional top-down approaches, and is an essential part of Sustainable Livelihood (SL) programs (FAO 2000). It is a customer-focused program where the targeted group participates in the entire process, learning about the situation, identifying problems, discussing alternatives, selecting solutions, designing and implementing activities, evaluating and disseminating results (Chat 2000). In these processes, target groups share their traditional knowledge to identify problems and solutions, ensuring the poor and uninformed will not be excluded from development opportunities. This also creates a forum where outsiders can work with the community and help to improve their specific capacities (Chat 2000).

Nepal is rich in water resources, and fishing is a longstanding tradition. The communities involved in fishing activities are mostly Tharu, Majhi, Malaha, Danuwar, Kewat, Bote, Mushar, Mukhiya, Darai, Kumal, Dangar, Jalari, Bantar, Rai and other poverty-laden ones. Swar (1980) estimated there were about 80,000 fishers; however, it is estimated that there has recently been a three- to five-fold increase in the fishing population due to the increasing population and deepening poverty in Nepal (Gurung 2003a).

As a result of lack of appreciable management, most water bodies of Nepal are over-fished and environmentally degraded threatening the biodiversity and livelihood of traditional communities (Bhandari 1998, Karki and Thomas 2004). In this article, we present an example of sustainable participatory fishery management practices which has been successful in improving the livelihood of the fishers' community substantially around Phewa Lake (Pokhara, Nepal). 


\section{Beginning of the participatory approach to fishery}

The Agriculture Research Station (Fisheries), Pokhara, established in 1962 to improve the livelihood of poor people through sustainable fishery, is a major stakeholder of this participatory approach. Its relation with local fishers was strengthened in 1972 when the caged fish culture program was initiated with the cooperation of the Food and Agriculture Organization (FAO), the United Nations Development Program (UNDP) and Ministry of Agriculture and Co-operatives, His Majesty's Government of Nepal. To organize the local fishers, mainly nomadic Jalari, in a forum where issues on participatory

TABLE 1. Cage fish culture production rate $\left(\mathrm{kg} \cdot \mathrm{m}^{-3} \cdot \mathrm{y}^{-1}\right)$ in Phewa Lake

\begin{tabular}{lll}
\hline Year & Production rate & Source \\
\hline 1979 & 5.5 & Pradhan and Shrestha (1979) \\
\hline 1980 & 3.4 & Wagle (2000) \\
\hline 1985 & 3.4 & Swar and Pradhan (1992) \\
\hline 1990 & 1.33 & Sharma (1990) \\
\hline 1998 & 5.0 & Wagle (2000) \\
\hline 2000 & 3.5 & Present study \\
\hline 2001 & 4.3 & Present study \\
\hline 2002 & 4.4 & Present study \\
\hline
\end{tabular}

TABLE 2. Family number, cage holding and fish harvest from cage fish culture in Phewa Lake

\begin{tabular}{llllll}
\hline Year & $\begin{array}{l}\text { Number } \\
\text { of } \\
\text { families }\end{array}$ & $\begin{array}{l}\text { Number } \\
\text { of cages }\end{array}$ & $\begin{array}{l}\text { Fingerlings } \\
\text { stocked }\end{array}$ & \multicolumn{2}{c}{ Fish harvest } \\
\cline { 5 - 6 } & & & Number & $\begin{array}{l}\text { Weight } \\
\mathbf{( k g )}\end{array}$ \\
\hline 2000 & 56 & 213 & 107500 & 63500 & 37274 \\
\hline 2001 & 58 & 227 & 144500 & 68100 & 47000 \\
\hline 2002 & 58 & 253 & 127000 & 75900 & 48300 \\
\hline
\end{tabular}

Source: Fish Grower's Association, Phewa Lake, Pokhara fisheries management could be discussed, a fisheries association known as Matsya Byawasayi Samitee Kaski was founded. Fewa Matsya Byawasayi Samitee (FMBS), Nepali version of 'Phewa Committee of Fishers' was established as a wing of this organization. The District Agriculture Development Office and the Agriculture Development Bank of Kaski are also the main stakeholders in their joint effort.

At first the fisher families were trained to manage cage fish culture in the lake. Later, unsecured loans were offered for cage material and fingerlings (Swar and Pradhan 1992, Gurung and Bista 2003). The FMBS later formulated code of conduct for gill net operation (the cage fish culture in the lake), marketing and loan repayment systems. The major strategies adopted in the participatory approach were community mobilization for resource management and conservation, and fish stocking enhancement.

\section{Characteristic features of Phewa Lake}

Phewa Lake is situated at the southwestern edge of Pokhara Valley $\left(28^{\circ} 1^{\prime} \mathrm{N}, 82^{\circ} 5^{\prime} \mathrm{E}\right.$, alt. $\left.742 \mathrm{~m}\right)$ with a watershed area of approximately $110 \mathrm{~km}^{2}$ (Ferro and Swar 1978). The total surface area of the lake was estimated at 500 ha by Ferro and Swar (1978), while Rai et al. (1995) reported 523 ha. More recently, Lamichhane (2000) estimated 443 ha of water surface area with a maximum depth of $23 \mathrm{~m}$. Phewa Lake is fed by two perennial streams: Harpan Khola and Andheri Khola, as well as several seasonal streams.

The lake has a single outlet, where water is diverted for irrigation and hydropower generation. About 1700 wooden plank boats and other craft are operating in the lake, mainly for tourism services. It is estimated that $16 \%$ of Pokhara's total income is generated through tourism (Oli 1997), and the shorelines of Phewa Lake, especially the western side, comprise one of the most popular tourist spots, with many hotels and restaurants.

Several studies have revealed the mesotrophic status of Phewa Lake (Ferro 1980, 1981/82, Fleming 1981, Nakanishi et al. 1988, Rai 1998, Davis et al. 1998). Presently, the lake is facing severe environmental problems as a result of nutrient loading from agriculture, landslides, and rapid urbanization in the surrounding area. Sewage from the surrounding settlements is directed into the lake (Lamichhane 2000), and the volume

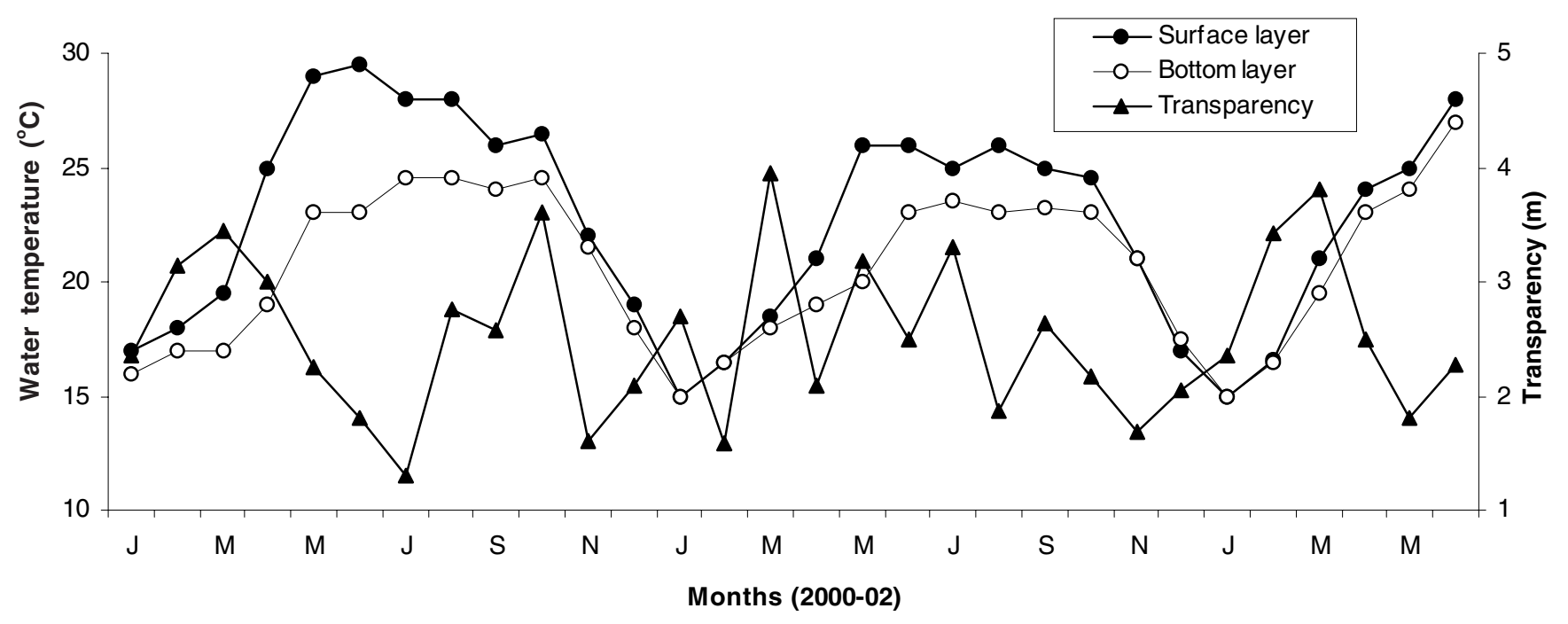

FIGURE 1. Seasonal changes in water temperature and transparency in Phewa Lake 
continues to rise dramatically in response to increased tourism (Oli 1997). The recent trend is toward rapid eutrophication (Oli 1997, Lamichhane 2000, Rai 2000). However, the lake is also seasonally oligotrophic due to heavy rainfall in its wider catchment area (Rai 2000). Phewa Lake receives as much as ten times more run-off during the monsoon season that the rest of the year (Ferro 1981/82). The lake is now infested with a floating macrophyte, the water hyacinth, Eichhornia crassipes, and blue green algae indicating enriched nutrient loading into the lake.

Phewa Lake's water temperature ranges between 15 and $29^{\circ} \mathrm{C}$ and transparency varies between 1.2 to $4.1 \mathrm{~m}$ (Figure 1 ). In the study period, the lowest transparency was recorded in July 2000 due to monsoon siltation, and the highest in March 2001 , probably due to the low productivity of the water in winter.

\section{Cage fish culture in Phewa Lake}

Fish in the cages at Phewa Lake exclusively depend on plankton that contains nitrogen $(\mathrm{N})$ and phosphorus $(\mathrm{P})$. These two nutrients are major elements responsible for eutrophication. Since fish becomes the food for humans, N and P are displaced from the lake to the land (Pradhan and Pantha 1995). Therefore, the subsistence cage farming is often cited as an environment friendly livelihood approach.

Cage fish culture of plankton feeder fish in nylon or polyethylene knot-less floating cages of approximately $5 \mathrm{~m}$ x 5 $\mathrm{m} \times 2 \mathrm{~m}$ is a popular method of fish production in the lake (Swar and Pradhan 1992, Gurung 2001). Silver carp (Hypophthalmichthys molitrix) and bighead carp (Aristichthys nobilis) are reared at the rate of 10 fish $\mathrm{m}^{-3}$. The farmer stocks 25 g fingerlings in $25-35 \mathrm{~mm}$ mesh cage and they become harvestable at 500-1000 g in 12-15 months (Rai 2000). Cages may yield $1.33-5.5 \mathrm{~kg}$ of fish per cubic meter per year, depending on the trophic status of the lake (Table 1), excluding losses of $10-20 \%$ due to mortality and escape.

Fish production from cage culture was $37 \mathrm{mt}$ in 2000, while in 2002 it reached to $48.3 \mathrm{mt}$ (Table 2). In addition, 6-8 $\mathrm{mt}$ of fish are produced annually in experimental cages by the Fisheries Research Station, Pokhara. In 2001, the total cage fish production was estimated to be $52 \mathrm{mt}$.

Monetary income from 4-5 cages was adequate to cover all expenses of a typical fisher family comprising 5 members for a year (Swar and Pradhan 1992). To begin with, each family was given a single cage, which only provided partial support for the family (Sharma 1990), but the number of cages was increased later (Table 2). The supply of quality fingerlings became the main bottleneck. This was resolved when a fish hatchery constructed in Pokhara under the aegis of HMG Nepal and Japan International Cooperation Agency (JICA) (Gurung and Bista 2003)

Now some fishers owning as many as 16 cages are producing about $3000-4000 \mathrm{~kg}$ of marketable fish per annum (Table 2,3). The annual income of these fishers comes to approximately 200-300 thousand Nepalese rupees, equivalent to US \$2850-4280 at the current exchange rate of $70 \mathrm{NR}=$ US\$ (Gurung and Bista 2003). The fishers now pay 30-50 thousand Nepalese Rupees annually as an income tax to the District Development Committee after the fish harvest. Most families now own their land, have houses with toilets, gas stove, and TV; a few also possess motorbikes. With the increased income and improving livelihood, community members are able to send their children to school; at present, a dozen students are ready to attend university. A few years ago, it was difficult to find a single literate member of the community (Gurung and Bista 2003).

\section{Open water fishery}

Fishing is the traditional occupation of Pode or Jalari in Pokhara, capture fishery using gill nets of mesh size up to $200 \mathrm{~mm}$ was widely adopted during the 1960s (Rajbanshi et al. 1984, Swar and Gurung 1988). Since 1975, the participatory approach has been encouraging the fisher community to utilize their

TABLE 3. Number of production and nursery cages hold by fisher's family in Phewa Lake

\begin{tabular}{ll}
\hline Number of families & Number of cages owned by each family \\
\hline 5 & $15-20$ \\
\hline 10 & $10-15$ \\
\hline 34 & $5-9$ \\
\hline 8 & $1-4$ \\
\hline
\end{tabular}

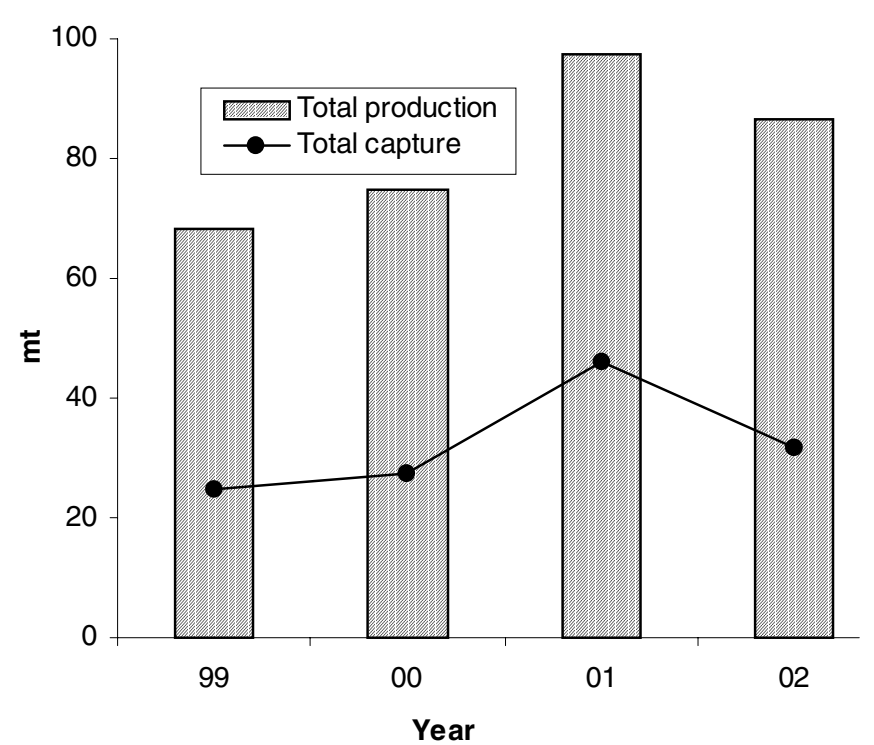

FIGURE 2. Total fish production and contribution of total captured fishery in Phewa Lake (Source: FMBS, Pokhara)

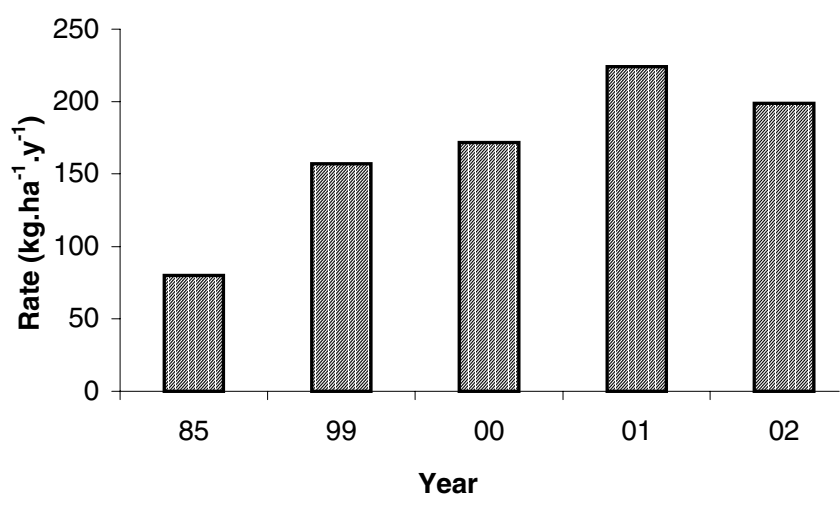

FIGURE 3. Annual fish production rate of Lake Phewa 
traditional skills and helping them earn livelihood easily. This requires releasing (restocking) finger sized baby fish (fingerling) into the lake and re-catching later (recapture) when they grow bigger (Swar and Gurung 1988, Shrestha et al. 2001) using fishing devices like gill net, cast net, line, hook etc.

The main native species that form the basis of Phewa Lake fishery are Tor spp, Acrossocheilus hexagonolepis, Labeo dero, Cirrihina reba, Mastacembelus armatus, Barilius spp., and Puntius spp. (Ferro 1980, Bista et al. 2002). The fishery in Phewa Lake is comprised of exotic and indigenous fishes with substantial contribution of the former (Wagle and Bista 1999). The native and exotic fish species contributing to capture fishery are listed in Table 4. Their contribution is ranked as high, medium and low on the basis of annual abundance in catch statistics.

The total annual fish production ranged from 65 to $98 \mathrm{mt}$ in Phewa Lake between 1999 and 2002, out of which $46 \mathrm{mt}$ were captured in 2001 and $31 \mathrm{mt}$ in 2002 (Figure 2). Wagle and Bista (1999) reported a $50.7 \mathrm{mt}$ fish catch in Phewa Lake which included a $20 \%$ augmentation of the recorded catch to account for unrecorded harvest.

The total fish production in Phewa Lake reached about $98 \mathrm{mt}$ in 2001 (Figure 2) contributing up to 219 $\mathrm{kg} \cdot \mathrm{ha}^{-1} \cdot \mathrm{y}^{-1}$ (Figure 3). Mean fish production rate from reservoirs in Asia was estimated to be $20 \mathrm{~kg} \cdot \mathrm{ha}^{-1} \cdot \mathrm{y}^{-1}$ (De Silva 1988) suggesting that Phewa Lake is much more productive than average Asian reservoir.

\section{Market channeling}

Pokhara city is a traditional market for fish products; however, market channeling must be improved. Given the national consumption rate of $1.5 \mathrm{~kg}$ per capita (Gurung 2003a) and Pokhara's population of about 300,000, approximately $1.5 \mathrm{mt}$ of fish can be easily sold every day in the local market. Only a small portion of the total fish production of Pokhara valley is marketed in adjacent districts and Kathmandu, mostly during winter when yield surpasses local consumption. In summer, when fish catch is low, fish is supplied to Pokhara from outside sources.

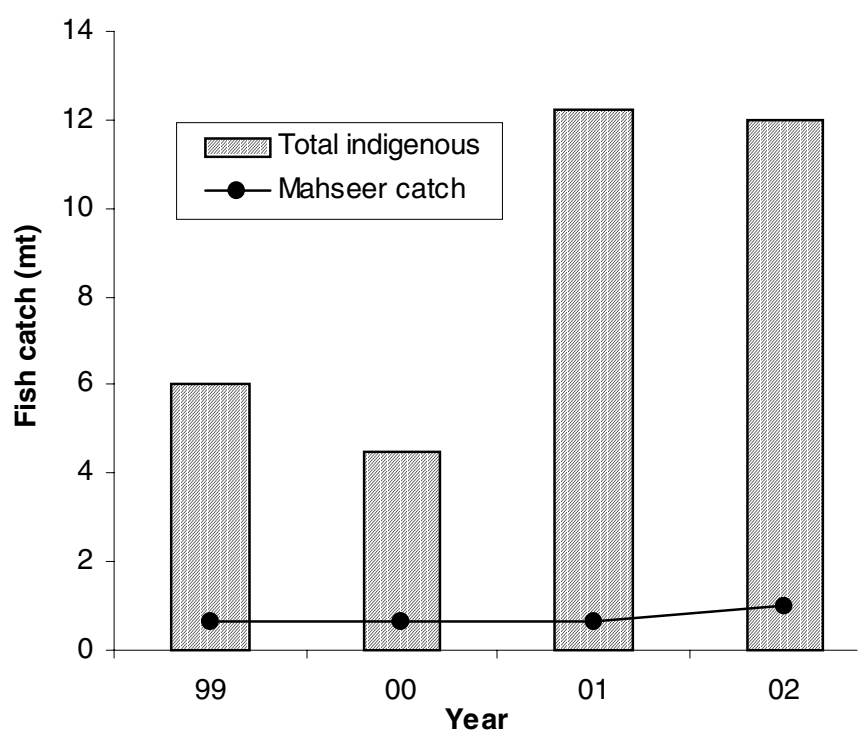

FIGURE 4. Total indigenous fish catch and contribution of T. spp (Mahseer) in Phewa Lake
Market arrangement for cage cultured fish and loan repayment

A multi-stakeholder body that includes FMBS, Agriculture Research Station (Fisheries), Agriculture Development Office and local fish-marketers determine the wholesale price of fish. The FMBS determines the turn for marketing each owner's fish. Fish are harvested early in the morning and brought to the office premises located nearby the lake around $6 \mathrm{AM}$, where, farmers are given a coupon to specify what was delivered, and the fish is turned over to a contractor for marketing. The contractor returns to the fisheries office to pay for the fish after selling it. The fishers are then paid according to the coupon

TABLE 4. Fish species and their contribution in capture fishery of Phewa Lake

\begin{tabular}{|c|c|c|}
\hline Scientific name & Local name & Contribution* \\
\hline Tor putitora (Hamilton) & Sahar & Low \\
\hline Tor tor (Hamilton) & Sahar & - \\
\hline $\begin{array}{l}\text { Acrossocheilus hexagonolepis } \\
\text { (McClelland) }\end{array}$ & Katle & Low \\
\hline Cirrihina reba (Hamilton) & Rewa & Medium \\
\hline $\begin{array}{l}\text { Mastacembelus armatus } \\
\text { (Lacepede) }\end{array}$ & Chuche bam & Low \\
\hline Xenentodon cancila (Hamilton) & Dhunge bam & Medium \\
\hline Channa gachua (Hamilton) & Bhoti & Low \\
\hline Channa striatus (Bloch) & Bhoti & Low \\
\hline Barilius barna (Hamilton) & Lam Fageta & High \\
\hline B. bola (Hamilton) & Fageta & High \\
\hline B. vagra (Hamilton) & Faketa & High \\
\hline Barilius bendelisis (Hamilton) & Fageta & High \\
\hline Mystus bleekeri (Day) & Junge & Low \\
\hline Puntius sophore (Hamilton) & Bhitte & High \\
\hline P. sarana (Hamilton) & Kande & High \\
\hline P. titius (Hamilton) & Bhitte & High \\
\hline P. ticto (Hamilton) & Bhitte & High \\
\hline $\begin{array}{l}\text { Nemacheilus rupicola } \\
\text { (McClelland) }\end{array}$ & Gadela & Low \\
\hline Garra annaldalei (Hora) & Buduna & Low \\
\hline Clarias batrachus (L.) & Magur & Low \\
\hline $\begin{array}{l}\text { Psilorynchus pseudochenesis } \\
\text { (Menon \& Dutta) }\end{array}$ & Tite & Low \\
\hline Cirrhinus mrigala (Hamilton) & Naini & Low \\
\hline Catla catla (Hamilton) & Bhakur & Low \\
\hline Labeo rohita (Hamilton) & Rohu & Medium \\
\hline Aristichthys nobilis (Richardson) & Bighead carp & High \\
\hline $\begin{array}{l}\text { Hypophthalmichthys molitrix } \\
\text { (Valenciennes) }\end{array}$ & Silver carp & High \\
\hline $\begin{array}{l}\text { Ctenopharyngodon idella } \\
\text { (Valenciennes) }\end{array}$ & Grass carp & Low \\
\hline Cyprinus carpio (L.) & Common carp & Low \\
\hline
\end{tabular}


tendered. If they have to pay loan, $50 \%$ amount of earning is deducted for repayment. In order to secure the best price, many fishers deliver their live product.

Market arrangement for recaptured fish

The marketing of recaptured fish (caught after being restocked; restocking is the act of releasing baby fish into the lake to increase fish population) is well organized. Women fisher themselves sell smaller fish weighing less than $2 \mathrm{~kg}$ each collected near the shoreline in the local market. A contractor may purchase recaptured fish larger than $2 \mathrm{~kg}$ each, which are collected every morning and brought to a chilling center located at the southern edge of the lake, where fresh, processed fillet and smoked products are sold.

\section{Conservation initiative}

A substantial quantity of Mahseer (Tor spp.) and other native fish were caught every year during ‘60s in Phewa Lake (Ferro 1980). However, the population was largely depleted and the catch fishery of Mahseer declined sharply, contributing less than $1.4 \mathrm{mt} \cdot \mathrm{y}^{-1}$ (Figure 4).

There are 23 native fishes reported in Phewa Lake. The abundance of some fish has changed over time. For instance, Channa spp. and Clarias batrachus have been appeared more frequently in catches, which was not the case earlier. Katle (Acrossocheilus hexagonolepis) populations have decreased noticeably. Until 1960s, people catched a mahseer as big as 40 $\mathrm{kg}$ (personal communication with local fishers), but now only smaller individuals $(\leq 10 \mathrm{~kg})$ are caught. Mahseer is vulnerable during spawning season, when they migrate towards shallow inlet stream for breeding. To protect these spawners, the fisher community has formed groups on their own initiative to patrol inlet streams during the breeding season (monsoon) and suppress illegal fishing (Gurung 2003b). Women's groups have also been mobilized, and they have proven more effective than their male counterparts at controlling fishing. It appears that few traditional fishers indulge in non-conventional techniques such as the use of electricity, explosives and poisons. Instead, these practices are more typical of urban people visiting the Phewa Lake area. Recently, the fisher community has also been engaged in manual removal of water hyacinth and other invasive macrophytes from the lake.

\section{Code of conduct for sustainable fisheries management}

Citizens of both developed and developing countries have a stake in environment, for both their health and that of their children (Downes and Brennan 1998). They now understand that environmental protection and sustainable use of resources such as lake and forest are fundamental to long-term prosperity (Downes and Brennan 1998, FAO 2002). Accordingly, the fisher community in close cooperation with other stakeholders has formulated the following code of conduct:

i. Fishing zone: Fishing in lake by any means is prohibited around $100 \mathrm{~m}$ of the Ratna Mandir, Fisheries Research Center, the Barahi temple and the inlet stream of Harpan Khola.

ii. Fishing method: Fishing using explosive, chemicals and battery operated electric rods are prohibited. Fishing by hook and line, gill net, and cast net are allowed, except in restricted areas and monsoon seasons. However, gill nets with mesh smaller than $100 \mathrm{~mm}$ is not allowed in the offshore of the lake.

iii. Fish culture areas: Cages for fish culture can only be set at three locations in the lake. The permitted sites are Khapaudi, in front of Fisheries Research Center and Sedi Area.

\section{Lessons learned}

The lessons learned from the participatory fisheries approach in recent decades are:

- Participatory programs in a community, which comprises socially deprived and ethnic minorities takes a long time to become self-sustaining in the mainstay of the society.

- The participatory approach to fishery can only be sustainable if the income generated is substantial and adequate to support the involved families.

- Deprived communities are inclined to depend on their stakeholder for various needs in addition to technical support

- The quality of twine, cage and net materials available in Pokhara for fish farming is very poor. In the near future attempts should be made to initiate local production of quality gear for fishing and fish farming.

\section{Implications}

The successful application of the participatory fisheries program of Phewa Lake has been implemented in other lakes of Pokhara Valley, Kulekhani Reservoir in Makawanpur District, and some parts of mid and far western development regions of the country. In Kulekhani area, community displaced by the construction of the Kulekhani hydropower dam has been resettled and provided a source of income and employment through cage fish culture and capture fisheries management. Besides the hydropower reservoirs, hundreds of shallow lakes, swamps, wetlands and inundated areas exist in southern plains (Bhandari 1998). In such waters implementation of participatory fishery managements can improve the livelihood of local communities and protect aquatic environments.

Costa-Pierce (1998) argued that cage aquaculture in Indonesian Reservoir is neither environmentally nor socially sustainable. The cage aquaculture was originally guaranteed to the displaced people by provincial legislation, and they were supposed to be granted exclusive control of production and marketing. However the rewards of cage culture have been usurped by the politically powerful and consolidated in the hands of the urban rich. On the other hand, management of the extensive cage fish farming system in Phewa Lake is fully controlled by the fisher community; it is essential that this system be maintained. Recent reports indicate that tourism activities can adversely affect the ecology of pristine ecosystems through the loading of nutrients into the water column (King and Mace 1974, Liddle and Scorgio 1980, Hadwen et at. 2003). Such studies have not been yet carried out in Nepal, though Phewa Lake is under intense pressure from tourism development (Oli 1997, Lamichhane 2000). Since tourism is one of the most lucrative economic sectors fostering around Phewa Lake, adequate attention must be paid to sustainable management of the lake ecosystem so that tourism and fishery may develop 
synergistically rather than adversarially.

\section{Conclusions}

The threats to sustainability of Phewa Lake are sedimentation, eutrophication and heavy infestation of water hyacinth. If these are controlled, the life of the lake could be improved and lengthened. It is anticipated that fishers can contribute to the sustainable management of Phewa Lake, if they are allowed to participate fully and share their skills and traditional knowledge. Since, the participatory management of natural resources in Phewa Lake has been proved to be an important avenue for sustainable livelihood enhancement of poor, it is anticipated that several other water bodies could be wisely managed to bring deprived fisher communities into the mainstream of society.

\section{Acknowledgements}

Our work was supported by a series of grants from the Ministry of Agriculture and Cooperatives, Nepal Agriculture Research Council (Project No.62359001), FAO/UNDP, JICA and Hill Agricultural Research Program (HARP: PP: 00/46) of Department for International Development (DFID).

\section{References}

Berkes F, R Mahon, P McConney, R Pollnac, R Pomeroy (eds). 2001. Managing mall-scale fisheries: Alternative directions and method. Ottawa: International Development Research Centre (IDRC). $250 \mathrm{p}$

Bhandari B. 1998. An inventory of Nepal's Terai wetlands. Wetland and Heritage Unit. Kathmandu, Nepal: IUCN. xvi +309 p

Bista JD, RP Dhakal and TB Gurung. 2002. Changing environmental status and their impact on flora and fauna of two major lakes (Phewa and Rupa) of mid hill region, Pokhara, Nepal. In: Neupane FP, KM Bajracharya (eds), International Seminar on Mountains, Kathmandu. Proceedings of the symposium at the Royal Nepal Academy of Sciences and Technology (RONAST); 2002 March 6-8; Kathmandu, Nepal Roya Nepal Academy of Sciences and Technology (RONAST). p 447-456

Campbell J and V Salagrama. 2000. New approaches in participation in fisheries research. A discussion document commissioned by Food and Agriculture Organization (FAO) and Center for Inland Fisheries and Aquaculture Research (CIFAR). $60 \mathrm{p}$

Chat TT. 2000. An experience with participatory research in Tam Giang Lagoon, Thua Thien-Hue. Network of Aquaculture Centers in Asia (NACA), STREAM Journal. 1:3-4

Costa-Pierce BA. 1998. Constraints to the sustainability of cage aquaculture for resettlement from hydropower dams in Asia: An Indonesian case study. Journal of Environment and Development 7: 333-368

Davis MF, TB Gurung, BC Shrestha, SB Jones, GDWylie, BD Perkins and JR Jones. 1998. Use of subsurface plankton layer to benefit a cage culture fishery in Lake Phewa, Nepal. Verh. Internat. Verein. Limnol 26: 940 947

Downes DR and VD Brennan. 1998. Fisheries conservation and trade rules: Ensuring that trade law promotes sustainable fisheries. Washington, DC: Center for International Environmental Law, Greenpeace. 77 p

De Silva SS. 1988. Reservoirs in Sri Lanka and their fisheries. Food and Agriculture Organization. Fisheries Technical Paper. No. 298. 128 p

FAO. 2000. Report on the workshop on participatory approaches in aquaculture Bangkok, Thailand, held on 28 Feb-1 Mar 2000. Rome: Food and Agriculture Organization, Fisheries Report No.630.41 p

FAO. 2002. Code of conduct for responsible fisheries. Rome, Italy: Food and Agriculture Organization. Available: http://www.fao.org/fi/agreem/ codecond/codecon.asp. via the INTERNET Accessed 2005 Jan 9

FerroW. 1980. Data on the fishery in Pokhara Valley and their implication for the fishery management. Journal of the Institute of Science 3: 225-236

Ferro W. 1981/82. Limnology of the Pokhara Valley Lakes (Nepal). Journal of Nepalese Research Centre V/Vl: 27-52

FerroW and DB Swar. 1978. Bathymetric maps from three lakes in the Pokhara Valley, Nepal. Journal of the Institute of Science 1: 177-188

FlemingWM. 1981. Phewa Tal management program: Benefits and costs of forestry and soil conservation in Asia and the Pacific. In: LS Hamilton (ed), Forest and watershed development and conservation in asia and the pacific. Boulder, Colorodo: Westview Press. p 217-288

Gurung TB. 2001. A review on status, potentiality and limitation of cage fish culture in Nepal. A Report submitted to Hill Agriculture Research Program of DFID, Kathmandu, Nepal. $15 \mathrm{p}$

Gurung TB. 2003a. Fisheries and aquaculture activities in Nepal. Aquaculture Asia VIII(1): 14-19
Gurung TB. 2003b. Traditional fishers work to save fish species in Nepal's lakes. Washington DC: WorldWildlife Fund. $\mathrm{p} 1$ and 5

Gurung TB and JD Bista. 2003. Livelihood improvements through fisheries in the Pode community in Pokhara, Nepal. STREAM Journal 2(3): 1-2

Hadwen WL, AH Arthington and TD Mosisch. 2003. The impact of tourism on dune lakes on Fraser Islan, Australia. Lakes \& Reservoir: Research and Management 8: 15-26

Jiggins J and H Zeeuw. 1992. Participatory technology development in practice: process and methods. In: Reijntjes C, B Haverkort and A Waters-Bayer (eds), Farming for the future: An introduction to lowexternal-input and sustainable agriculture. London: MacMillan. $\mathrm{p}$ 135-162

Karki S and S Thomas (eds).2004. A review of the status and threats to wetland in Nepal. Kathmandu, Nepal: International Union for Nature Conservation (IUCN). 78+v p

King JG and ACJ Mace. 1974. Effects of recreation on water quality. Journal of Water Pollution Control Federation 46: 2453-2459

Liddle MJ and HRA Scorgio. 1980. The effects of recreation on freshwater plants and animals: A review. Biological Conservation 17: 183-206

Lamichhane DB. 2000. Phewa Lake watershed area: studies on settlements and environmental appraisal. Pokhara, Nepal: Kul Bahadur Lamicchane. $140 \mathrm{p}$

Nakanishi M, MMWatanabe, A Terashima, YSako, T Konda, K Shrestha, HR Bhandary, Y Ishida. 1988. Studies on some limnological variables in subtropical lakes of the Pokhara Valley, Nepal. Japan Journal of Limnology 49: 71-86

Oli KP (ed). 1997. Phewa lake conservation action plan. Kathmandu, Nepal: International Union for Nature Conservation (IUCN). $75 \mathrm{p}$

Pradhan BR and BC Shrestha. 1979. Economic analysis of cage fish culture in Pokhara Valley, Nepal. In: The Proceedings of IVth National Fisheries Seminar; 1979 Nov 22-29. Kathmandu, Nepal: Fisheries Development Section, Department of Agriculture, p 46-56

Pradhan GBN and MB Pantha. 1995. Report on a regional study and workshop on the environmental assessment and managaement of aquaculture development (TCP/RAS/2253). NACA Environmental Aquaculture Development Series No. 1. Bangkok, Thailand: Network of Aquaculture Centers in Asia-Pacific p 293-313

Rai AK. 2000. Evaluation of natural food for planktivorous fish in lakes of Phewa, Begnas and Rupa in Pokhara Valley, Nepal. Limnology 1: 81-89

Rai AK. 1998. Trophic status of Fewa, Begnas and Rupa Lakes in Pokhara Valley, Nepal: Past, present and future. Journal of Lake Sciences 10: 181-201

Rai AK, BC Shrestha, PL Joshi, TB Gurung, M Nakanishi. 1995. Bathymetric maps of lakes Phewa, Begnas and Rupa in Pokhara Valley, Nepal. Memoirs Faculty of Science Kyoto University. $16 \mathrm{p}$

Rajbanshi KG, BR Pradhan and DB Swar. 1984. Aquaculture practices in Lake Begnas, Pokhara Valley, Nepal. Proceeding of the II ${ }^{\text {nd }}$ Meeting, IndoPacific Fisheries Commission Working Party, New Delhi, India. p 1-10

Sharma BP. 1990. Economic of cage culture of carps in the lakes of Pokhara Valley, Nepal. Report submitted to International Development Research Centre, Canada. $71 \mathrm{p}$

Shrestha MK, RK Batajoo and GB Karki. 2001. Prospects of fisheries enhancement and aquaculture in lakes and reservoir of Nepal. Paper presented in symposium on 'Coldwater fishes in the Trans Himalayan Region'. 2001 July 10-13, Kathmandu, Nepal organized by Fisheries Development Directorate/ FAO/ IUCN/WWF

Swar DB. 1980. Present status of limnological studies and research in Nepal. Paper presented at the XX1st Congress of Association of Theoretical and Applied Limnology, Kyoto, Japan

Swar DB and BR Pradhan. 1992. Cage fish culture in lakes of Pokhara Valley, Nepal, and its impact on local fishers. Asian Fisheries Science 5: 1-13

Swar DB and TB Gurung. 1988. Introduction and cage culture of exotic carps and their impact on fish harvested in Lake Begnas, Nepal. Hydrobiologia 166: 277-283

Van de Fliert E, R Asmunati and W Tantowijoya. 1999. Participatory approaches and scaling up. Paper presented at the Centro Internacional Agricultura Tropical Workshop on 'Working with farmers: The key to adoption of forage technologies', 12-15 October 1999, Cayagan de Oro, Phillipines. $12 \mathrm{p}$

Wagle SK. 2000. Technical, social and environmental consideration of cage fish culture in Lakes of Pokhara Valley, Nepal. A paper presented to study team headed by Director General, Department of Fisheries, Bangladesh at Agriculture Research Station (Fisheries), Pokhara on 12th June 2000. 4 p

Wagle SK and JD Bista. 1999. Catch efforts and capture fishery in lakes of Pokhara valley: status and management perspective: In: Neopane SP and R C Khanal (eds), Proceedings of 3rd national workshop on livestock and fisheries research in Nepal. Lalitpur, Nepal: Nepal Agricultural Research Council. p 53-69 